\title{
Development of a CD-ROM on written language for the continuing education of elementary school teachers
}

\author{
Thaís dos Santos GONÇALVES ${ }^{1}$, Patrícia Abreu Pinheiro CRENITTE²
}

\begin{abstract}
1- Speech-Language Pathologist, MSc student, Department of Speech-Language Pathology and Audiology Bauru School of Dentistry, University of São Paulo, Bauru, SP, Brazil.

2- PhD, Clinical Medicine, Professor, Department of Speech-Language Pathology and Audiology, Bauru School of Dentistry, University of São Paulo, Bauru, SP, Brazil.
\end{abstract}

Corresponding address: Thaís dos Santos Gonçalves - Alameda Dr. Octávio Pinheiro Brisolla, 14-75 - ap. 4 - $17012-191$ - Vila Universitária - Bauru - SP - Brasil Phone: (14) 8123-8315 - (14) 3221-3741 - e-mail: thaiscarpediem@yahoo.com.br

Received: July 24, 2010 - Accepted: August 16, 2011

\section{ABSTRACT}

\begin{abstract}
Distance education has emerged to minimize the anxiety of many professionals who need to update their knowledge, but do not have the time and opportunity to travel to educational centers. Objectives: To describe the development of a CD-ROM to provide distance continuing education to basic school teachers that addresses issues related to written language. Material and Methods: Previously, a script was developed with themes related to the acquisition and development of written language. Subsequently, a technical team transformed the texts in multimedia language. Results: The titles of each content area addressed are available on buttons and links. The files can be viewed in a linear sequence, allowing the teacher to start learning at the desired moment and go straight to the file that he or she wants to access. Videos that show practical applications of the concepts available in text are included. Conclusions: Brazil is a developing country. The use of technologies for education reduces cultural isolation among education professionals. It is necessary to focus on making teaching materials for distance education. In order to provide an effective learning environment, the learners reality should be considered. A multidisciplinary team should prepare the materials. The development of educational material for distance education on the acquisition and development of written language seems not only appropriate, but also warranted to provide professional growth opportunity for teachers who need time flexibility and/or live far away from academic centers.
\end{abstract}

Key words: Distance education. Continuing education. Educational technology. Speech, language and hearing sciences.

\section{INTRODUCTION}

Despite the numerous expectations of teacher educators around the world, few researchers have focused on the development of a curriculum for educating teacher educators ${ }^{9}$. Results of studies on distance education in teacher education have shown that teachers use the technologies in creative ways, highlighting the importance of these teachers' abilities to face the challenges of the knowledge society ${ }^{21}$.

Professional development in any field is an ongoing process that takes place over the entire career; therefore, the need for educational initiatives in the continuing education process is unquestionable ${ }^{18}$. Distance education (DE) has emerged to minimize the anxiety of many professionals who feel the need to update their knowledge, but do not have time to go to educational centers. DE permits them to overcome geographical boundaries. In addition, it enables students to improve themselves at their own pace in their home or workplace. Thus, DE may represent an effective democratization of education ${ }^{27}$. In Brazilian legislation, DE is conceptualized as a form of education that enables self-learning 
with the mediation of systematically organized learning resources ${ }^{6}$. DE is a promising strategy in teacher development in a country with continental dimensions, such as Brazil, that presents a large contingent of teachers with multiple needs and shortcomings in their conceptual repertoires ${ }^{24}$.

The continuing education courses must have real meaning for teachers' work. Knowledge of acquisition and development of written language is extremely important for elementary school teachers because they deal with these teaching activities on a daily basis. It is also important that these professionals detect the presence of written language disorders early. Frequently, they are unable to achieve this goal ${ }^{11}$.

This study describes the preparation of distance education material with the purpose of providing primary school teachers with an interactive course to gain knowledge related to the acquisition and development of written language.

\section{MATERIAL AND METHODS}

\section{Contextualization of the problem}

At the Departments of Speech Pathology and Pediatric Dentistry, Orthodontics and Community Health, Bauru School of Dentistry of the University of São Paulo, several studies were conducted that examined the knowledge of elementary school teachers and students of the pedagogy of phonologic alterations ${ }^{7,11}$. Despite the importance of teachers' knowing about the development of human communication and related disorders, these studies showed that these professionals possessed little knowledge in these areas. In relation to written language, the results of studies showed that teachers had little knowledge of reading and writing disorders ${ }^{11}$. In the authors' experience of this study, through the university extension in Monte Negro, in Rondonia, teachers in that location also had limited knowledge regarding the aspects of written language. Further, they were interested in learning more about this theme, although they did not have access to institutions that provided such knowledge.

Due to this lack of information in the area, which was not restricted to one location, an idea was formulated to overcome geographical boundaries and bring knowledge to teachers through a distance learning course. Therefore, DE is a teaching modality that is favorable to the goals and needs of continuing education for teachers, offering a solution to this problem.

\section{Aim of the course}

The course was intended to provide information about the normal written language acquisition and development processes. Teachers should be alert when students did not properly follow these procedures, and must identify these alterations. The knowledge about expected processes facilitates the diagnosis and early interventions for disorders of written language. In addition, the course aims to reflect upon the relationship among the various factors that influence student learning.

\section{Choice of the material for DE}

Several tools were analyzed for transmission of the desired content, considering the socioeconomic conditions and teachers' needs. An asynchronous tool was chosen. Therefore, the information would not be received at the same time as it was transmitted. This tool allows for greater flexibility of study time. The following options were studied: e-mail (digital form of correspondence sent via the Internet); discussion groups or list (information exchange via messages among various members of a virtual community with similar interests); downloaded files containing audio, text, images, or videos; websites; digital versatile discs (DVDs); and compact disk read-only memory (CD-ROM). However, the proposal involved applying the content in different locations, as there were teachers in some regions of the country with limited access to the Internet. Therefore, the tools that did not need the Internet and had were the DVD and CD-ROM. Both permit the simultaneous use of visual (text, animation, images, videos) and auditory (sound, voice, music) media and have a large storage capacity. Presenting a large amount of information promotes learning; they can even be transported. To use a DVD, individuals need a device or a computer with a specific type of reader. Currently, several CD-ROMs are being created for distance education, as they are attractive and inexpensive ${ }^{10}$. The CD-ROM can be used on any computer that has a CD-ROM drive (or reader), which is still found on most computers, as compared to the DVD player.

\section{CD-ROM setup}

To prepare the CD-ROM, a script was first drawn with themes related to the acquisition and development of written language, which created relevant questions that are commonly encountered by teachers in their school practice. Thus, the script was constituted as follows:

1. HOME/TITLE - Acquisition and development of written language: electronic manual for teachers

2. PRESENTATION/CREDITS

3. INTRODUCTION

a. Speech therapist's role in schools

b. Importance of partnership between teacher and speech therapist

4. REQUIREMENTS FOR ACQUISITION OF READING AND WRITING

a. In relation to children 
b. In relation to teachers

c. In relation to schools

5. THE ACQUISITION AND DEVELOPMENT OF THE READING AND WRITING PROCESS

\section{READING PROCESS}

The technical aspect of the preparation of the CD-ROM was made by the Technological Laboratory of Applied Information (TLAI), which is a research and extension group of the Department of Computer Science Faculty at Univ. Estadual Paulista - UNESP. The group is dedicated to convergence technologies and digital technology in education, which currently offers the following undergraduate and graduate courses: Information Systems and Computer Science and Design. In these courses, the written material was turned into multimedia language.

\section{RESULTS}

The script presented refers to the titles of each content area, which are available on buttons and links. The files can be viewed in a sequence, allowing the teacher to start the learning process when they want and leads to the desired topic (see Figures 1 and 2). Videos were included that showed the practical applications of some concepts available in the text.

In the lower left corner of both figures, tools can be found that are responsible for an increase or decrease in the font size in the selected text, according to the comfort level of the learner. Another tool can also be viewed that is responsible for dragging the text up or down and replacing the scroll bar. It is located on the right side.

At the end of each content area, the learner is presented with the option to print the text. The "help" ("ajuda") button can be seen in both figures. This tool can be accessed by the teacher if he or she has trouble handling the CD.

\section{DISCUSSION}

The idea that DE is inferior to the presential classes is being challenged every day because of many students' experiences with this teaching modality ${ }^{19}$. The literature regarding this theme indicates that DE is an appropriate and effective strategy for adult education that is already in the labor market ${ }^{2}$. Universities that adopt DE as an educational modality save money without sacrificing quality. In addition, the effectiveness of the DE is related to the time flexibility, which is no longer found in education ${ }^{15}$. DE also offers an individualized study that is adjusted to the pace of the learner, who selects when and where to study. DE is also a fast and efficient way to train and qualify professionals ${ }^{23}$.

Due to increased demand for education and training in the information age, online learning and teaching is becoming a necessity. However, limited research aimed at understanding the impact of online learning environments on students is a problem $^{22}$. The CD-ROM has been proposed for use in DE in undergraduate Speech Pathology and Audiology. A CD-ROM was prepared to cover the theme "Auricular Molding". Its effectiveness was evaluated by second-year students. In this study, a statistically significant difference was found in

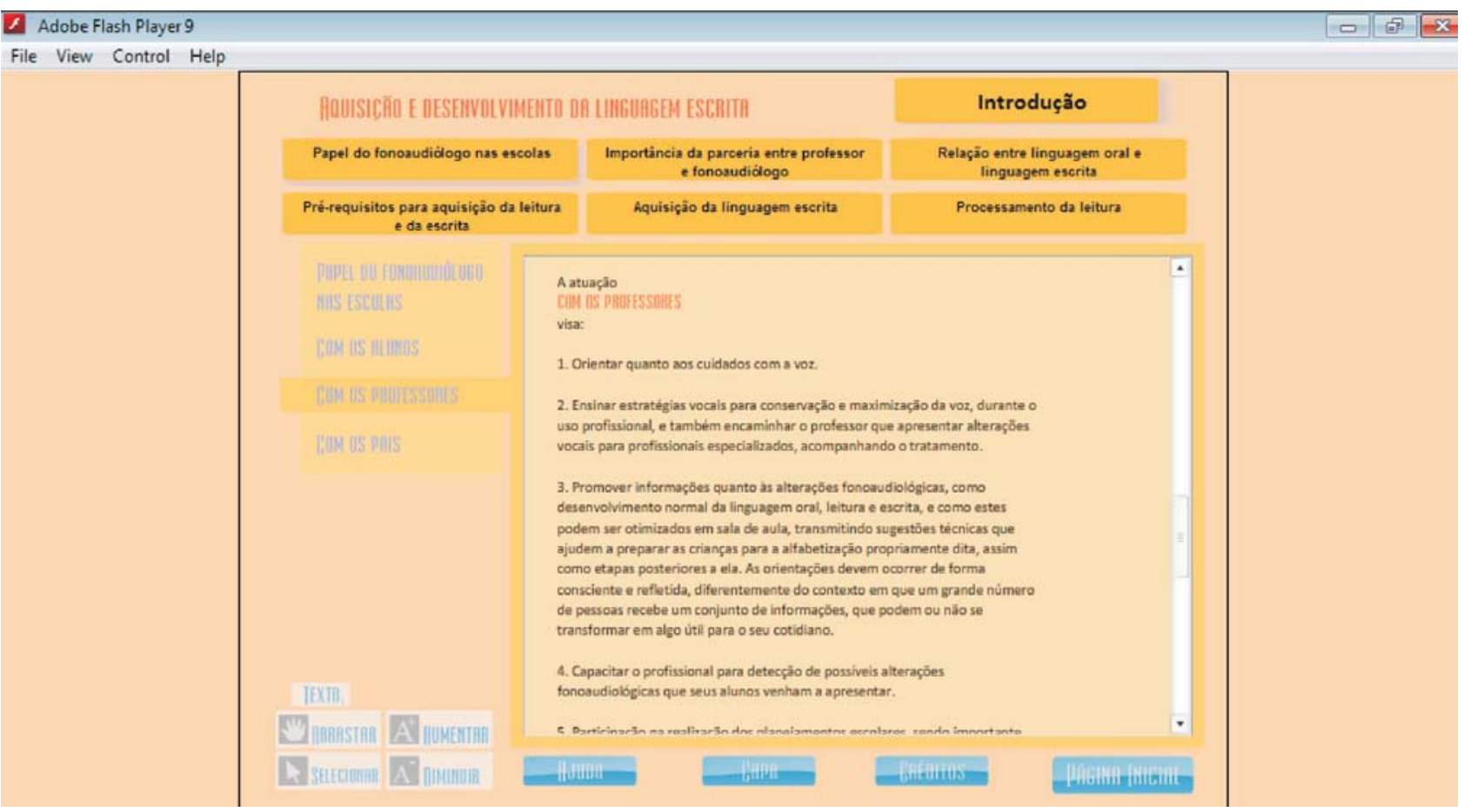

Figure 1- Content involving the speech therapist's role in schools 
the knowledge levels before and after the course. Therefore, the material enabled the learning of undergraduate students, proving its effectiveness as a teaching material ${ }^{4}$.

Another study was conducted to evaluate the efficacy of the Virtual Man Project's CD-ROM entitled "Voice Assessment: Speech-Language Pathology and Audiology \& Medicine" as a self-learning tool in two different populations: Speech-Language Pathology and Audiology students and Lyrical Singing students. The comparison of responses (before and after studying the CD-ROM) showed a statistically significant increase in the knowledge scores after studying the CD-ROM for both groups of students. It was concluded that this didactic material was an effective instrument for selflearning in these populations ${ }^{25}$.

The choice of technological resources should be initiated by the usability, ease, and adequacy requirements of the public, rather than the sophistication and complexity. There are simpler and less expensive technologies that are very effective for learning ${ }^{1}$. Therefore, this developed material was adapted to the socioeconomic reality of the country, and the material preparation was inexpensive. Therefore, the developed material was consistent with the needs and interests of teachers to acquire such knowledge.

There is no education without teachers; consequently, human resources should always be valued $^{1}$. In this sense, the idea is that the teacher, who realizes the proposed distance course, provides advice during and after the course. Learning in this environment involves more than operating equipment and programs with dexterity. The ability to learn to click the correct place on the screen is not enough to follow a course in this modality. It should be a pedagogical preparation for the online environment and include required training or specific skills to this type of education ${ }^{1}$. For this reason, the authors of this study are members of the League of Telehealth of the Bauru School of Dentistry, which is a broadcast course. This league has the purpose of developing activities in telehealth and tele-education, providing courses that prepare members to deal with the online environment.

To decrease the need for the educator to be present, it is important to have elaborate materials that are self-explanatory with good recourse, such as links, supporting text, glossaries, and activities. This involves assembling an interdisciplinary team with people from technical and pedagogical areas who can work together and make significant contributions ${ }^{20}$. Thus, the development of teaching materials requires interdisciplinary groups (i.e., academic teams with computer professionals, particularly web designers, who are capable of providing the materials produced in electronic media) and discussions about the kind of language to be adopted in the production of this material ${ }^{3}$. So, in the development of this material, there was a partnership with TLAI to produce the electronic media.

In $\mathrm{DE}$, course preparation has the propensity to

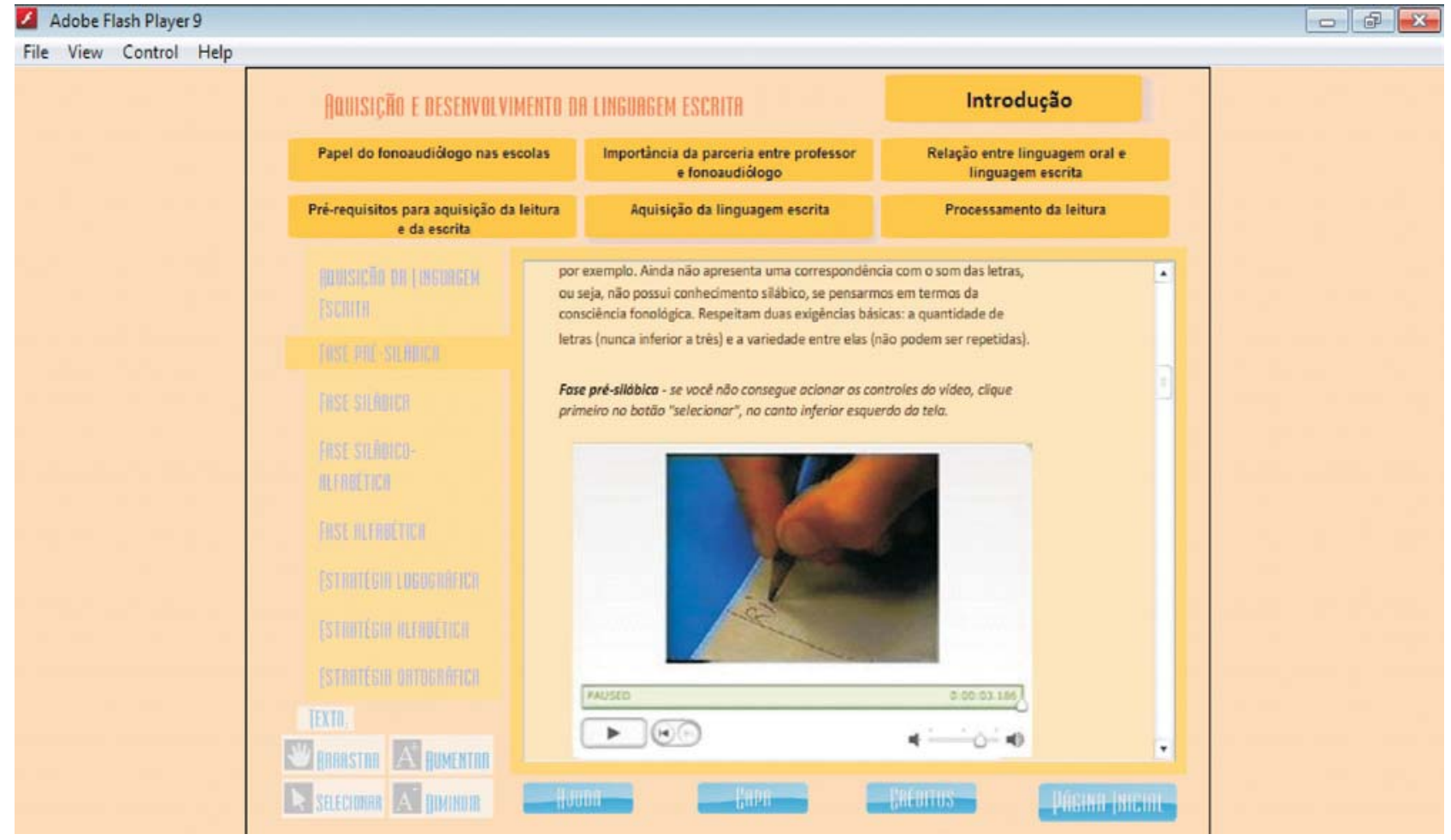

Figure 2- Content involving the acquisition of written language 
consume a greater amount of time than that of a traditional course. The conversion of the prepared material to a new format and the offering of the course require a significant amount of time and organization. This consumption of time is higher due the meticulous selection and presentation of the images and videos in the material and the determination of how the content will be displayed on a computer screen. Team discussions in the process of formulating the material are also timeconsuming, as they require the contribution of each team member to produce material that is truly effective.

Beyond the role of knowledge producer, the distance educator assumes responsibility for the motivation of the students ${ }^{8}$. Information about the characteristics of personal formation enables them to know the needs of each learner and plan a suitable learning environment for them ${ }^{17}$. Thus, this material provides insights that were applicable by teachers in the classroom, which was a motivating factor.

In the context of $\mathrm{DE}$, a review was conducted on the role of the educator ${ }^{12}$. The continuous learning process is no longer a solitary, individualistic, and competitive process. On the contrary, it is a collective exercise of knowledge production. It is expected that with the application of this material, there is also an experience exchange in which the authors of this study can offer their expertise in the area. Moreover, teachers can collaborate in the classroom, thereby producing a collective knowledge.

Online courses can promote equality among learners with different knowledge level ${ }^{1}$. Both presential and distance learning course quality depends on the presence of intellectually and emotionally mature educators and curious individuals who know how to motivate and engage learners. The great teacher is attractive not only due to their ideas, but also due to their personal contacts. Also, it depends upon the learners. That is, the curiosity and motivation of students greatly facilitate the process and encourage the best qualities of the teacher ${ }^{20}$. It is recommended that educators develop teaching strategies that focus on the learners, who should identify themselves as primarily responsible for learning. Following this reasoning, the virtual learning environment should also promote the creation of situations that stimulate the students to develop activities that value autonomy, creativity, and reflective thought, which are fundamental for teaching and learning. The course should be applied to teachers who genuinely show interest in acquiring such knowledge, so that the curiosity and desire for the themes make the process of distance education easier and more effective, thereby decreasing the avoidance of these teachers in the course.

To illustrate the use of distance learning in professionals' continuing education, educational material was prepared targeting an audience of physicians involved in treating breast cancer. The course was structured in a virtual learning environment via the Internet. The scope of the course reached eight cities in four states. The results showed that it is necessary to break the cultural barriers related to this form of learning. Based on the difficulties in this study and in order to improve the program, it was concluded that knowledge of the student's profile facilitates dialogue and negotiations in the learning process, which should be adapted to its rhythms and differences. The organization of the course must provide information and clear evaluation criteria and deadlines. In addition, the method allows the students to manage their learning autonomously ${ }^{16}$.

Regardless of the study subject, it is essential that learning occurs collaboratively. The CD-ROM is the first stage of the educational proposal, providing allowances resulting in the need to search and enable the interaction with classmates and the educator. The student may also seek grants from other sources, such as books, and Internet research, participating in an active way ${ }^{12}$. With the application of this developed material, we wanted to awaken the teachers who might be the builders of their own knowledge, showing that they can learn, despite having completed graduation.

The use of animations and videos can be essential to promoting student's motivation, as it breaks the monotony of reading texts ${ }^{3}$. Therefore, we decided to include videos in this material to make it more attractive and to facilitate information retention. An Australian study was conducted on the development of a CD-ROM aimed at examining the professional development of teachers in the area of statistics by comparing the same content presented on a CD-ROM, book, and video. Teachers in the pilot group commented that the video was easiest to use, whereas the CD-ROM was the most difficult to use. This was not a surprising result, as many teachers had not accessed a CD-ROM before. The time needed to download movies was a problem for some computers. The teachers reported that they needed to use printouts to avoid reading from the computer screen or to take periodic breaks from reading the screen. Further, they emphasized the combination of personal contact with multimedia features during learning. It was concluded that the combination of text, video, and CD-ROM seemed to bring more satisfaction to the learner ${ }^{26}$. Therefore, a printing tool was included and videos were inserted into the content of the developed material.

The teacher often has no awareness of his or her role as mediator in the knowledge construction 
of students. Numerous factors are very important to the orientation: the development of written language, strategies to optimize it, situations that encourage the development of narrative skills, and spelling and its relationship with speech ${ }^{28}$. Most often, teachers do not know that the learning process depends of many factors; they frequently think that it depends only on the student. This can occur because teachers do not have enough knowledge about this theme during their university education. Because of the importance and necessity of this theme, this course addressed the acquisition and development of written language aspects. Then, the teacher reflectively learns the content available. Further, their students' learning depends upon teachers' methodology, posture, and relationship with students.

Continuing education is important for the teacher to constantly update and develop the skills necessary in their practice ${ }^{13}$. In general, it is assumed that more public resources are spent on continuing education than on teacher formation in undergraduate courses in public institutions ${ }^{14}$.

The Law of Education Directives and Bases (LDBEN, Law No. 9.394/96) states in Article 67 that educational systems should promote the appreciation of educational professionals. Section II holds that continuing education is an obligation of public authorities. In Article 80, it states that the government should encourage the development and diffusion of DE programs in all levels and learning modalities and in continuing education ${ }^{5}$.

\section{CONCLUSION}

Teachers are responsible for their continuing education and must, therefore, seek ways to accomplish it. Through DE, teachers can reconstruct their knowledge, taking into account their own experience in the classroom.

To complete the proposed course, it is important that teachers require monitoring, as they may have questions that are not fully resolved by the material. This teacher monitoring also allows for the exchange of information and ideas between the speech therapist and the teacher that should be valued. As previously discussed, DE does not replace the educator role, but turns it into that of a director, showing that there are several ways of learning. Therefore, this work showed a manner of using technological resources in education, taking into account the experience of both parties (i.e., those who produce and provide the course and those who perform it). Both involve learning beyond a professional integration of pedagogy and speech therapy, contributing to the improvement of the education in the country. Consequently, other proposals may emerge and be applied in this and other areas of speech therapy.

Brazil is a developing country. The use of technologies for education reduces the cultural isolation of educational professionals. The teaching materials in DE need to consider the reality of the learners in order to provide effective learning. In order for the purposes of DE be achieved, a multidisciplinary team is essential in preparing the material because it is necessary the experience of both areas: learning and technology.

Given these considerations, the development of educational material for distance education on the acquisition and development of written language seems not only appropriate, but also warranted to provide professional growth opportunity for teachers who need time flexibility and/or live far away from academic centers.

The literature related to Speech Therapy and other areas of knowledge is scarce regarding the preparation and effectiveness of DE materials. This is a teaching modality that is growing every day worldwide. With the first results of the application of this course, it is possible to make necessary changes for its optimization, which can be used in graduate courses of pedagogy and speech therapy.

\section{ACKNOWLEDGMENT}

This study was a sub-project funded by the State of São Paulo Research Foundation - FAPESP, process no. 2008/02397-7, in the category of "Public Education" entitled "Using a CD-ROM resource to improve knowledge of communication disorders among elementary school teachers".

\section{REFERENCES}

1- Azevedo W. Como "detonar" com um projeto de educação online. In: Silva M, ed. Educação online: teorias, práticas, legislação e formação corporativa. São Paulo: Loyola; 2003. p. 155-8.

2- Bastos MAR, Guimarães EMP. Educação à distância na área da Enfermagem: relato de uma experiência. Rev Latino-Am Enfermagem. 2003;11:685-91.

3- Belisário A. O material didático na educação à distância e a constituição de propostas interativas. In: Silva M, ed. Educação online: teorias, práticas, legislação e formação corporativa. São Paulo: Loyola; 2003. p. 135-46.

4- Blasca WQ, Bevilacqua MC. A multimídia como uma nova proposta de ensino da audiologia. Salusvita. 2006;25:113-26.

5- Brasil. Lei de Diretrizes e Bases da Educação Nacional 9394/96 de 20 de Dezembro de 1996. Estabelece as diretrizes e bases da educação nacional. Diário Oficial da União, Brasília (1996 Dec. 23); v.134, n. 248.

6- Brasil. Ministério da Educação. Secretaria de Educação. Parâmetros curriculares nacionais - Ensino Médio. Brasília: MEC; 2001.

7- Calais LL, Jorge TM, Crenitte PAP. Conhecimento dos professores do ensino fundamental sobre a gagueira. Pró-Fono. 2002;14:2330 .

8- Candido MCFS, Furegato ARF. Transtornos depressivos: um material didático para educação à distância. Esc Anna Nery Rev Enferm. 2008;12:473-8. 
9- Cochran-Smith M. Learning and unlearning: the education of teacher educators. Teaching and Teacher Education. 2003;19:528.

10- Conde SJ, Ishara KL, Nishida SM, Diniz RES. Proposta de CDROM sobre comportamento sexual dos animais para a disciplina de Biologia do Ensino Médio [online]. S.d. [cited 2011 Aug 23]. Available from: http://www.unesp.br/prograd/PDFNE2003/ Proposta\%20de\%20CD-Rom.pdf

11- Fernandes GB, Crenitte PAP. O conhecimento de professores de $1^{a}$ a $4^{a}$ série quanto aos distúrbios da leitura e escrita. Rev. CEFAC. 2008; 10:182-90.

12- Ferrés ]. Entrevista [entrevista concedida a Maria Lucia Badejo]. Pátio: revista pedagógica. 1999;3:24-7.

13- Gasque KCG, Costa SMS. Comportamento dos professores da educação básica na busca da informação para formação continuada. Ci Inf. 2003;32:54-61.

14- Gatti BA. Análise das políticas públicas para formação continuada no Brasil, na última década. Rev Bras Educ. 2008; 13:57-70.

15- Hollis V, Madill H. Online learning: the potential for occupational therapy education. Occup Ther Int. 2006;13:61-78.

16- Kelmer S, Coelho-Oliveira A, Fonseca, LMB. Educação à distância mediada pela internet: "Linfonodo sentinela, prevenção, diagnóstico precoce e biópsia - nova técnica de abordagem do câncer de mama". Radiol Bras. 2007;40:251-4.

17- Laaser W. Manual de criação e elaboração de materiais para educação a distância. Brasília: Editora Universidade de Brasília; 1997.

18- Marin AJ. Educação continuada: reflexos e alternativas. Campinas: Papirus; 2000.

19- Matkin GW. Distance education: its concepts and constructs. J Vet Med Educ. 2007;34:220-5.
20- Moran JM, Masetto MT, Behrens MA. Novas tecnologias e mediação pedagógica. 7a ed. Campinas: Papirus; 2002.

21- Oliveira-Bueno B, Oliveira AS. Distance education in another register: uses and appropriation of technologies in teacher education. Univ Psychol. 2008;7:823-36.

22- Oncu S, Cakir H. Research in online learning environments: priorities and methodologies. Computers \& Education. 2011;57:1098-108.

23- Padallino Y, Peres HHC. E-learning: a comparative study for knowledge apprehension among nurses. Rev Latino-Am Enfermagem. 2007;15:397-403.

24- Pesce L. Educação a distância: novas perspectivas à formação de educadores. In: Moraes MC, ed. Educação a distância: fundamentos e práticas. Campinas: UNICAMP/NIED; 2002.

25- Vieira MMRM, Berretin-Felix G, Brasolotto AG. The Virtual Man Project's CD-ROM "Voice assessment: Speech-Language Pathology and Audiology \& Medicine", Vol.1. J Appl Oral Sci. 2009;17(Suppl):43-9.

26- Watson JM. Professional development for teachers of Probability and Statistics: into an era of technology. International Statistical Review. 2007;66:271-89.

27- Zanette EM, Nicoleit ER, Nicoleit, GFG. A produção do material didático no contexto cooperativo e colaborativo da disciplina de Cálculo Diferencial e Integral I, na modalidade de Educação a Distância, na Graduação. Novas Tecnologias na Educação. 2006;4:1-9.

28 -Zorzi JL. O que devemos saber a respeito da linguagem escrita e seus distúrbios: indo além da clínica. In: Andrade CRF, Marcondes E. Fonoaudiologia em Pediatria. São Paulo: Sarvier; 2003. p 130-2. 